\title{
The Concept of "Vocalese" in the Class of FLE
}

\author{
Cynthia George
}

\begin{abstract}
Music is a world within itself a language we all understand "- Steve Wonder. According to these words if this language called "Music" can be used in the teaching of a foreign language it justifies the words of Plato "Music is a more potent instrument than any other form of education because rhythm and harmony find their way into the inward places of the soul". This article aims To highlight the advantages of "Vocalese" in the teaching of French as a foreign langue (FLE) - Francais Langue Etrangere and to structure a formative and fun FLE course through the exploitation of a song aiming at functional, linguistic and socio cultural objectives. Why use songs? Why music? Music is a therapy. It is a communication far more powerful than words, far more immediate and far more efficient" - Yehudi Menuhin. Having understood well the advantages of using songs in the teaching of FLE, let us now analyze the concept the "Vocalese". What is Vocalese? Vocalese is a style or musical genre of jazz singing wherein words are sung note for note to melodies that were originally created by a soloist's improvisation. Why use Vocalese? Man can learn nothing except by going from the known to the unknown - Claude Bernard (French physiologist).In "Vocalese" one is familiar with the tune. When this (known) tune is combined with new lyrics (the unknown) learning is facilitated. Advantages of "Vocalese" in the concept of teaching - Vocalese uses the deductive method of teaching in lieu to the inductive method of teaching. Music is to soul what words are to mind and if these words can be altered it is nothing more than the alteration of the mind - the very first step needed in the teaching of any language. Thus the duty of every teacher is not to teach but to facilitate teaching in accordance to the words of Robert Frost "There are two kinds of teachers: the kind that fills you with so much quail shot that you can't move and the kind that just gives you a little prod behind and you jump to the skies". I conclude with the words of Albert Einstein "It is the supreme art of the teacher to awaken joy in creative expression and knowledge" and I as a teacher would like to awaken this joy via music and would prefer to be called an "Educational Rock Star"
\end{abstract}

Keywords:-Music, Vocales, Teaching, ELE.

\section{INTRODUCTION}

"Music is a world within itself a language we all understand "-Steve Wonder

According to these words if this language called "Music" can be used in the teaching of a foreign language it justifies the words of Plato “"Music is a stronger instrument when compared with any other sort of education since rhythm along with harmony get their technique into the back to the inside places on the soul"”

\section{Aim: This article aims}

- To highlight the advantages of "Vocalese" in the teaching of French as a foreign langue (FLE) Francais Langue Etrangere.

Revised Manuscript Received on April 22, 2019.

Ms. Cynthia George, M.A - French, UGC NET, Assistant Professor in French, Providence College for Women Spring Field, Bandishola, Coonoor, Tamil Nadu.
- To structure a formative and fun FLE course through the exploitation of a song aiming at functional, linguistic and socio cultural objectives.

Why use songs? Why music?

Music is a therapy. It is just a communication significantly more powerful when compared with words, alot more immediate and much more efficient" - Yehudi Menuhin

Inclusion of music/ songs into the teaching methodology is one of the best ways to teach any foreign language because

1. Music creates positive vibes in the class

2. Songs ensures repetition and thus effective memorization of vocabulary

3. Songs enable better comprehension of culture

4. Various dialects and slangs can be introduced into the course using contemporary/ archived songs

5. The activity improves the spoken aspect of the language

6. Learners are all attentive in the same time

7. Activities using music are contextualized and / or playful.

8. Activities are not purely linguistic.

9. The activity multiplies the contacts within the group.

10. It reduces the teacher's speaking time for the benefit of learners.

Having understood well the advantages of using songs in the teaching of FLE, let us now analyze the concept the "Vocalese"

\section{What is Vocalese?}

Vocalese is a style or musical genre of jazz singing wherein words are sung not for note to melodies that were originally created by a soloist's improvisation Kurt Elling maybe there most well-known latest practitioner on the style, talks about the style consequently: "Although your message 'vocalise' was applied far more strictly for you to Jon Hendricks' work throughout big band/multi-voice settings, the idea quickly enhanced through standard use to indicate any you receive a vocally presented lyric based on tunes first noted by brighten instrumentalists, no matter if solos -a feat that can only have occurred with the coming of recorded seem -the beginning composers involving such song's lyrics essentially designed a new art. "

Why use Vocalese?

Man can learn nothing except by going from the known to the unknown - Claude Bernard (French physiologist) 
In "Vocalese" one is familiar with the tune. When this (known) tune is combined with new lyrics (the unknown) learning is facilitated.

\section{Example1}

"Why this kolaveri di": is a song from the soundtrack of the 2012 Tamil psychological thriller film, 3. The actual song is actually written as well as sung through Dhanush, Tamil actor and also composed simply by Music Movie director Anirudh Ravichander. It became probably the most streamed tracks of all-time. The track was formally released upon 16 Nov 2011 along with instantly grew to become viral in social networking sites because of its quirky "Tanglish " (portmanteau > word associated with Tamil in addition to English) words of the tune. Soon, the actual song grew to be the most looked YouTube video within India plus an internet trend across Asian countries. Within a couple weeks, YouTube privileged the video having a '"Recently The majority of Popular" Precious metal Medal Honor and "Trending" silver honor award with regard to receiving a large numbers of hits very quickly. Following the huge achievement and countrywide popularity Dhanush, the vocalist of the initial track had been invited at that same moment Prime Minister Dr . Manmohan Singh like a "Guest regarding Honour". New Lyrics to this existing sound track

Vous vous allez comment? Which means "How are you?" can be sung to the same tune as that of "Why this kolaveri"

Entammede Jimikki Kammal or perhaps Jimikki Kammal is a 2017 song in the soundtrack of your Malayalam flick Velipadinte Pusthakam (2017). The exact song is made up by Shaan Rahman together with sung by way of Vineeth Sreenivasan and Ranjith Unni. Obtained from various persons songs, "Jimikki Kammal" is usually written by Anil Panachooran. The very song started to be viral as well as produced numerous dance ranges uploaded by just fans online. Benny R. Nayarambalam, piece of software writer involving Velipadinte Pusthakam, suggested tunes director Shaan first a number of lines belonging to the "Jimmikki Kammal" to construct a similar music. But Benny was unlikely to use similar lines. Soon after composition, lyricist Anil Panachooran and Shaan decided to utilize same ranges. And representative Lal Jose agreed to the idea. Later Anil added identical folk facial lines to the tune. The melody was released being a promo online video for the DVD on seventeenth August. Instantaneously the songs became a winner and several boogie video slip covers appeared throughout YouTube and also Facebook. Many among all these got virus-like status.

\section{New Lyrics to this existing sound track}

Toi, tu t'appelle comment?

Moi, Je m'appelle

"What is your name?

My name is

Can be sung in the same tune as that of "Jimiki Kamal".

\section{Advantages of "Vocalese" in the concept of teaching}

Vocalese uses typically the deductive technique of teaching instead to the initiatory method of instructing

Inductive vs. Deductive Language Teaching and Learning

Initiatory and deductive language instructing and knowing are very significant in training. They are not one

but two distinct plus opposing usage and discovering methods or maybe approaches. Both equally require the use of a teacher/instructor and a student/learner. The biggest dissimilarities between the couple of methods are definitely the focus and even flow associated with as well as the tasks of the trainer and scholar.

Inductive teaching: Initiatory teaching in addition to learning signifies that the route of the movement of information is usually from precise to standard. In terms of helping, the class is started off with pursuits or trials. It is typically focused on the scholars and their functions and talents, rather than about the teacher. There are several advantages of initial, initiatory teaching plus learning; experience is grabbed naturally by simply exposure, and even students really should utilize their very own reasoning knowledge, prior awareness, intelligence, together with mental target. This method likewise measures what sort of student helps make connections good information shown. Since initiatory teaching as well as learning consists of the student's perspective, it's easier to the student to find out the concept. Models under this procedure can be personal and easily recalled and realized. This is a technique of discovery and will be time consuming in addition to demanding of any student's creative imagination and ingenuity. Inductive schooling is properly suited for a smaller group of scholars with an experienced and encountered teacher whose to say how to make alterations throughout the wisdom.

Deductive teaching: The exact counterpart involving inductive assisting and knowing is deductive teaching along with learning. With this method, the exact role on the teacher can be prominent while he/she could be the person who presents and disseminates all information. The very flow detail in this technique is from standard to precise. The deductive method is the regular method of training and discovering. Knowledge is certainly taken from a broad reference or maybe source then communicated on the learner. The standard flow info begins while using concept's arrival and introduction followed by pursuits. Information will be based upon facts, phrases, and pre-determined logic The strategy is easy to make use of, leaves bit of room pertaining to mistakes, plus the information being shown is appropriate. There is also a obvious and outlined scope; the strategy requires minimal preparation about the part the very teacher. Nonetheless deductive educating also has their disadvantages that include a very strength and estimated flow. This procedure also foliage little place for connection, which makes can be effective just for larger multiple students.

Analaytical Results \& Discussions

- Reallocation of mind activity.

- Common point associated with address to some heterogeneous team.

- Enhances college student creativity as well as imagination.

- Enables inductive training in all areas namely -grammar, lexique and format.

- Spontaneous and also extempore. 


\section{Reallocation of brain activity:}

Expressive improvisation or even "free styling"spontaneously improvising words of the tune in actual timeis of a unique practical reallocation associated with brain action in the prefrontal cortex, based on a study regarding Scientific Reviews. Researchers within the voice, talk and dialect branch of the actual National Start on Deafness and Other Conversation Disorders in the National Study centers of Wellness used useful magnetic resonance imaging to analyze the brain exercise of artists as they improvised lyrics. These people scanned the particular brains involving 12 freestyle rap artists-each of who had a minimum of five many years of rapping experience-while the artists performed 2 tasks utilizing an identical eight-bar musical monitor.

For the very first task, artists improvised rhyming lyrics as well as rhythmic designs guided just by the defeat. In the 2nd task, these people performed the well-rehearsed group of lyrics. Throughout freestyle rapping, the experts observed raises in mind activity in the area responsible for inspiration of believed and activity, but reduced activity within regions which normally perform a remedies or checking role. As an experienced mother or father who knows if you should lay down regulations and when to appear the other method, these changes in human brain function might facilitate typically the free appearance of ideas and terms without the normal neural limitations. Further research of this system in some other art types that include the revolutionary use of language-such as beautifully constructed wording and storytelling-could offer much more insights in to the initial, improvisatory phase from the creative procedure.

\section{Common point of address to a heterogeneous group}

The teacher can choose any song from any language provided the group is conscious of the song. With reference to Tamil Nadu one may have a class with students whose mother tongues may be Tamil, Telugu, Malayalam, Paduga, and Hindi... In this heterogeneous group the teacher can choose any popular song from any language and use the same in the teaching of FLE

\section{Enhances student creativity and imagination}

The students can create their own vocaleses and thus it becomes a class of interaction in lieu of a teacher centered class. Multiple glossary, syntax and styles can be learnt by the combination of various songs and albums.

Enables inductive teaching in all fields namely grammar, lexique and syntax

Example 1: Analyzing the first example of "Why this kolaveri di?" in liason with "Vous vous allez comment?"

- Repetition enables memorization of vocabulary

- The rhythm and rhyme enables comprehension of syntax with regards to the grammatical elements of interrogation, reflexive and subject pronouns

- The special nuance of the language "Vous vous allez comment " -“ how do you go?"Instead of using the same format of "how are you?" in English is not taught to the student but noticed and enters the mind automatically with no specific strain to the brain.

\section{- Example 2:}

- The liason of "Jimki Kamal" with "Toi? Tu t'appelle comment?..."
- Again explains in detail the inductive teaching, the concept of "Tu t'appelle comment" - "How do you call yourself" instead of "What is your name" enables the student to analyze the nuances particular to each language.

- Spontaneous and Extempore: There is no need for previous preparation, it is on the spot and thus enables all students including ones irregular to class to actively participate in the activity.

\section{CONCLUSION}

- Music is to soul what words are to mind and if these words can be altered it is nothing more than the alteration of the mind - the very first step needed in the teaching of any language. Thus the duty of every teacher is not to teach but to facilitate teaching in accordance to the words of Robert Frost "There are two kinds of teachers: the kind that fills you with so much quail shot that you can't move and the kind that just gives you a little prod behind and you jump to the skies". I conclude with the words of Albert Einstein "It is the supreme art of the teacher to awaken joy in creative expression and knowledge" and I as a teacher would like to awaken this joy via music and would prefer to be called an "Educational Rock Star"

\section{REFERENCES}

1. Arora,N.(2012). English Language Teaching: Approaches and Methodologies. Tata McGraw Hill Education Private Limited.

2. Bourns,S.K.,Katz,S.L., \& Blyth,C.S. (2007). Teaching French Grammar in Context: Theory and Practice. Yale University Press.

3. Chapelle, C.A.(2016). Teaching Culture in Introductory Foreign Language Textbooks. Springer.

4. Dewaele, J.M.(Ed.). (2005). Focus on French as a Foreign Language: Multidisciplinary Approaches (Vol.10). Multilingual Matters.

5. Hancock,M. (2013). Singing Grammar Book and Audio CD: Teaching Grammar Through Songs. Cambridge University Press.

6. Lenka, O. (2011). The Use of Pop Songs in the EFL Classroom. Diplom.de

7. Russell, J., \& Cohn, R. (2012). Vocalese. Book on Demand.

8. West, T. (2001). Teaching American History with Favorite Folk Songs. Scholastic Inc.. 